https://doi.org/10.11646/zootaxa.4277.1.3

http://zoobank.org/urn:lsid:zoobank.org:pub:58DE9D03-DE8D-4FEF-84FE-46D353AFB347

\title{
Luciobarbus chelifensis and L. mascarensis, two new species from Algeria (Teleostei: Cyprinidae)
}

\author{
AMINA BRAHIMI ${ }^{1,5,6}$, JÖRG FREYHOF $^{2}$, ARNAUD HENRARD $^{3,4} \&$ ROLAND LIBOIS $^{5}$ \\ ${ }^{1}$ Department of Agronomy, University of Mohamed Kheider, BP 145 RP, 07000 Biskra, Algeria. E-mail: minagro005@yahoo.fr \\ ${ }^{2}$ Leibniz-Institute of Freshwater Ecology and Inland Fisheries (IGB), Müggelseedamm 310, 12587 Berlin, Germany. \\ E-mail: j.freyhof@igb-berlin.de \\ ${ }^{3}$ Earth and life Institute, Biodiversity research Center, UCL-17. 07. 04, Bâtiment Carnoy, Croix du Sud, 5, B-1348, Louvain-la-Neuve, \\ Belgium.E-mail: arnaud.henrard@uclouvain.be \\ ${ }^{4}$ Royal Museum for Central Africa, Leuvensesteenweg 13, 3080 Tervuren, Belgium. \\ ${ }^{5}$ Zoogeography Research Unit, Department of Biology, Ecology and Evolution, University of Liège, Chemin de la vallée 4 (Bât. B22) \\ 4000 Sart Tilman, Belgium.E-mail: roland.libois@ulg.ac.be \\ ${ }^{6}$ Corresponding author. E-mail: minagro005@yahoo.fr
}

\begin{abstract}
Cyprinids of the genus Luciobarbus are the most abundant and widespread fishes in most freshwater ecosystems in the Maghreb. In the Mediterranean basin of Morocco, Algeria and Tunisia, all species of Luciobarbus — with exception of $L$. guercifensis - are superficially very similar and are distinguished mostly by minor morphometric characters. Molecular characters distinguish all species well and nine species are recognised from the area, two of them described here. Luciobarbus chelifensis, from the Chelif River drainage in Algeria, is distinguished by having 41-43+1-2 lateral line scales and a very short anal fin (18-19\% SL). Luciobarbus mascarensis, from the Macta River drainage in Algeria, is distinguished by having usually 41+1-2 lateral line scales, a long anal-fin (19-22\%) and a short caudal peduncle (15-17\% SL). An identification key is given for all African Mediterranean Luciobarbus species except for L. callensis and L. rifensis, which could not be distinguished.
\end{abstract}

Key words: North Africa, Mediterranean biodiversity hotspot, Morphology, Cytochome b, D-loop control region

\section{Introduction}

Incomplete knowledge of biodiversity remains a stumbling block for conservation planning and even occurs within globally important Biodiversity Hotspots (Geiger et al. 2014). The Mediterranean area is one of these globally important Biodiversity Hotspots (Myers et al. 2000) and Geiger et al. (2014) pointed on a high number of potentially undescribed freshwater fishes in that area, including cyprinid fishes of the genus Luciobarbus from the Maghreb. Barbels of the genus Luciobarbus are widespread and species-rich in the Maghreb countries Tunisia, Algeria and Morocco. Almost all species had been described in the $19^{\text {th }}$ and early $20^{\text {th }}$ century and the last comprehensive reviews were published by Pellegrin $(1920,1939)$. In the early $21^{\text {st }}$ century, African Luciobarbus species had been involved in several molecular studies shedding some light to the diversity of this group of fishes (Machordom \& Doadrio 2001, Tsigenopoulos et al. 2003, Geiger et al. 2014, Brahimi et al. 2016). The results of these studies suggested the occurrence of several undescribed Luciobarbus species in the Maghreb. Only very recently, some Luciobarbus species groups have been reviewed and new species have been described (Casal-Lopez et al. 2015, Doadrio et al. 2016a, 2016b).

The above-mentioned studies suggest that six Luciobarbus species (Fig. 2) occur in the African rivers flowing to the Mediterranean Sea: L. rifensis in the Mediterranean Laou River drainage and some Atlantic rivers in Morocco, L. guercifensis and L. yahyaouii in the Moulouya River drainage and some small adjacent coastal rivers in Morocco, L. leptopogon in the small coastal rivers around Algiers in Algeria, L. setivimensis in the Soummam 
River drainage and some small rivers in the Bay of Bedjaia in Algeria and L. callensis being widespread in Tunisia west to the Kebir River drainage in eastern Algeria. Furthermore, L. biscariensis (Fig. 2) is widespread in the Shott Melghir basin, El Hodna (Keddara) lake basin and the Chiffa River drainage, all being endorheic waters in Algeria. Results from molecular studies (Tsigenopoulos et al. 2003, Geiger et al. 2014) indicate, that there might be one additional, undescribed Luciobarbus species in the Algerian Macta River drainage. During our studies, we found another undescribed species in the Algerian Chelif River drainage, not detected by previous studies. It is the aim of this study to describe these two new species.

\section{Material and methods}

Morphology. After anaesthesia, fishes were fixed in 5\% formaldehyde and stored in $70 \%$ ethanol or directly fixed in $99 \%$ ethanol. Measurements were made point-to-point, with a dial caliper and recorded to $0.1 \mathrm{~mm}$. Two measurements were taken over projections to the body axis: pre-dorsal length and pre-pelvic length. Other methods for measurements and all counts follow Kottelat \& Freyhof (2007). Standard length (SL) is measured from the tip of the snout to the posterior extremity of the hypural complex. The length of the caudal peduncle is measured from behind the base of the last anal-fin ray to the posterior extremitiy of the hypural complex, at mid-height of the caudal-fin base. The first unbranched dorsal and anal-fin rays are hidden in the skin and unbranched rays were counted from X-ray pictures. The position of the dorsal-fin origin was determined from x-ray pictures and not from preserved materials directly. The last two branched rays articulating on a single pterygiophore in the dorsal and anal fins are counted as "1 $1 \frac{1}{2} "$. Scales in lateral series are counted along the midlateral line from the first one to touch the shoulder girdle to the last scale at the posterior extremity of the hypural complex. The scales on the caudal-fin base are separated by + . The holotype is included in the calculation of ranges, means and SD.

Abbreviations used. SL, standard length; HL, lateral head length. Collection codes: FSJF, Fischsammlung J. Freyhof, Berlin; RMCA, Royal Museum for Central Africa, Tervuren; ZFMK, Zoologisches Forschungsmuseum A. Koenig, Bonn. Authors of species names are listed in Table 1.

TABLE 1. Species names mentioned in this study, and their authors.

Barbus barbus Linnaeus, 1758

Luciobarbus biscarensis (Boulenger, 1911)

Luciobarbus callensis (Valenciennes, 1842)

Luciobarbus guercifensis Doadrio, Perea \& Yahyaoui, in Doadrio, Casal-López, Perea \& Yahyaoui, 2016

Luciobarbus leptopogon (Schimper, 1834)

Luciobarbus setivimensis (Valenciennes, 1842)

Luciobarbus yahyaouii Doadrio, Casal-López \& Perea, 2016

Luciobarbus rifensis Doadrio, Casal-Lopez \& Yahyaoui in Casal-Lopez, Perea, Yahyaoui \& Doadrio, 2015

Molecular analysis. We were able to generate 53 new mitochondrial sequences (cyt b and D-loop) for eight Luciobarbus species (L. biscarensis, L. callensis, L. chelifensis, L. leptopogon, L. mascarensis, L. rifensis, $L$. setivimensis and L. yahyaouii). From NCBI Genbank, 28 additional mitochondrial sequences from African Mediterranean Luciobarbus species were downloaded (Table 2). Barbus barbus was used as outgroup. Polymerase chain reaction (PCR) amplification and sequencing were applied to two fragments of the mitochondrial genome: cytochrome b (cyt b) and D-loop control region, amplified using GLUDG.L (Palumbi 1996) and H16460 primers (Perdices \& Doadrio 2001) for cyt b, while the D-loop was amplified using L15923 (Iguchi et al. 1997) and H16500 primers (Nishida et al. 1998). Sequences for cyt b and D-loop were obtained with a length of 1140 bp and 470 bp respectively. All sequences were visualized and edited in SEQUENCHER v.5.2.4 (Gene Codes, USA) and then compared with other GenBank sequences in order to identify any undesirable contamination. The sequences were then aligned using MAFFT v.7 (Katoh \& Standley 2013) with default parameters. Alignment refinement was performed using Gblocks v.0.90b available on the Gblocks Server in order to eliminate poorly aligned positions and divergent regions (Talavera \& Castresana 2007). The sequences were concatenated into a single matrix in seaview v.4.5.4 (Gouy et al. 2010). All the analyses were performed on the combined mtDNA dataset (1610 bp). 
The concatenated was analysed in PartitionFinder v.2 (Lanfear et al. 2017) in order to select the best models per locus. The alignment dataset was then partitioned by gene and codon position into four: cyt $\mathrm{b}$ (the codons are partitioned into 1st, 2nd and 3rd positions) and D-loop. Maximum likelihood analyses (Felsenstein 1981) were implemented with GARLI v.2.1 (Bazinet et al. 2014) using the K80+G (Kimura 1980) F81+I (Felsenstein 1981), GTR $+\mathrm{G}$ (Lanave et al. 1984; Tavare 1986; Rodriguez et al. 1990) and HKY $+\mathrm{G}$ (Hasegawa et al. 1985) evolutionary models for cyt b 1st, 2nd and 3rd codons positions and D-loop, respectively, as suggested by PartitionFinder v.2 (Lanfear et al. 2017).

TABLE 2. Sequences from GenBank used in this study. Species, localities, the number of sequenced specimens and GenBank accession numbers (cyt b) are given.

\begin{tabular}{|c|c|c|c|}
\hline Species & Locality & Coordinates & GenBank Nr. \\
\hline Luciobarbus biscarensis & Abiod River, Biskra, Algeria & & AY004726 \\
\hline Luciobarbus biscarensis & Illizi, Algeria & & AY004724 \\
\hline Luciobarbus callensis & Abid River, Cap Bon, Tunisia & $36.867286^{\circ} \mathrm{N}, 10.724574^{\circ} \mathrm{E}$ & AY004878 \\
\hline Luciobarbus callensis & Sarrath River, Djerissa, Tunisia & $35.807531^{\circ} \mathrm{N}, 8.563658^{\circ} \mathrm{E}$ & AY004732 \\
\hline Luciobarbus callensis & Ain Assel reservoir, El-Taref, Algeria & $36.747037^{\circ} \mathrm{N}, 8.400955^{\circ} \mathrm{E}$ & AF045974 \\
\hline Luciobarbus leptopogon & Keddara reservoir, Boumrdèse, Algeria & $36.647275^{\circ} \mathrm{N}, 3.424412^{\circ} \mathrm{E}$ & AF145931 \\
\hline Luciobarbus leptopogon & Chiffa River, Blida, Algeria & $36.445279^{\circ} \mathrm{N}, 2.756340^{\circ} \mathrm{E}$ & AY004749 \\
\hline Luciobarbus mascarensis & Tifrit River, Balloul, Algeria & $34.987064^{\circ} \mathrm{N}, 0.408772^{\circ} \mathrm{E}$ & AY004743 \\
\hline Luciobarbus rifensis & Laou River, Derdara, Morocco & & KT003926 \\
\hline Luciobarbus rifensis & Laou River, Derdara, Morocco & & KT003927 \\
\hline Luciobarbus rifensis & Laou River, Derdara, Morocco & & KT003928 \\
\hline Luciobarbus rifensis & Laou River, Derdara, Morocco & & КT003929 \\
\hline Luciobarbus rifensis & Laou River, Derdara, Morocco & & KT003930 \\
\hline Luciobarbus rifensis & Hachef River, Dar Chaoui, Morocco & & KT003931 \\
\hline Luciobarbus rifensis & Hachef River, Dar Chaoui, Morocco & & KT003932 \\
\hline Luciobarbus rifensis & Hachef River, Dar Chaoui, Morocco & & KT003933 \\
\hline Luciobarbus rifensis & Hachef River, Dar Chaoui, Morocco & & KT003934 \\
\hline Luciobarbus rifensis & Hachef River, Dar Chaoui, Morocco & & KT003935 \\
\hline Luciobarbus rifensis & $\begin{array}{l}\text { Loukos River, Souk Had Laghdir, } \\
\text { Morocco }\end{array}$ & & KT003936 \\
\hline Luciobarbus rifensis & $\begin{array}{l}\text { Loukos River, Souk Had Laghdir, } \\
\text { Morocco }\end{array}$ & & KT003937 \\
\hline Luciobarbus rifensis & $\begin{array}{l}\text { Loukos River, Souk Had Laghdir, } \\
\text { Morocco }\end{array}$ & & KT003938 \\
\hline Luciobarbus rifensis & $\begin{array}{l}\text { Loukos River, Souk Had Laghdir, } \\
\text { Morocco }\end{array}$ & & KT003939 \\
\hline Luciobarbus rifensis & $\begin{array}{l}\text { Loukos River, Souk Had Laghdir, } \\
\text { Morocco }\end{array}$ & & KT003940 \\
\hline Luciobarbus setivimensis & Soummam River, Algeria & $36.632246^{\circ} \mathrm{N}, 4.74745^{\circ} \mathrm{E}$ & AY004748 \\
\hline Luciobarbus setivimensis & Aissi River, Tizi Ouzou, Algeria & $36.668968^{\circ} \mathrm{N}, 4.124125^{\circ} \mathrm{E}$ & AY015991 \\
\hline Luciobarbus setivimensis & Aissi River, Tizi Ouzou, Algeria & $36.668968^{\circ} \mathrm{N}, 4.124125^{\circ} \mathrm{E}$ & AY015992 \\
\hline Luciobarbus yahyaouii & Moulouya River, Boumia, Morocco & $32.801789^{\circ} \mathrm{N}, 4.791778^{\circ} \mathrm{W}$ & AY004742 \\
\hline Luciobarbus yahyaouii & Moulouya River, Morocco & $34.226706^{\circ} \mathrm{N}, 2.392343^{\circ} \mathrm{W}$ & AF145925 \\
\hline Barbus barbus & Danube River, Austria & & AB238965 \\
\hline
\end{tabular}


In total, 1000 bootstraps (BT) were obtained in four independent runs, each including 250 repetitions. BT values were then summarized on the best maximum likelihood tree using SumTree (Sukumaran \& Holder 2015) (run on DendroPy v.4.0.0; Sukumaran \& Holder 2010). The K80+G, F81+I, GTR $+\mathrm{G}$ and HKY+G models were incorporated into Bayesian inference, which was performed using four runs of Metropolis-coupled Markov Chain Monte Carlo (MCMC) sampling as implemented in the MrBayes program v.3.2.5 (Ronquist et al. 2012), using default model parameters as starting values. The following parameter settings were used: mchains $=4$; lset $\mathrm{nst}=2$, rates $=$ gamma (for $1 \mathrm{st}$ cyt $\mathrm{b}$ codons and D-loop); lset $\mathrm{nst}=2$, rates $=$ propinv (for 2 nd cyt $\mathrm{b}$ codons); lset $\mathrm{nst}=6$, rates $=$ gamma (for $3 \mathrm{rd}$ cyt b codons); mcmc ngen $=10,000,000$; sample freq $=1,000$. The trees were represented using Figtree v.1.4.2 (Rambaut 2009). The average uncorrected p-distances among African Mediterranean Luciobarbus species were calculated for the cyt b gene using MEGA v.6.0 (Tamura et al. 2013).

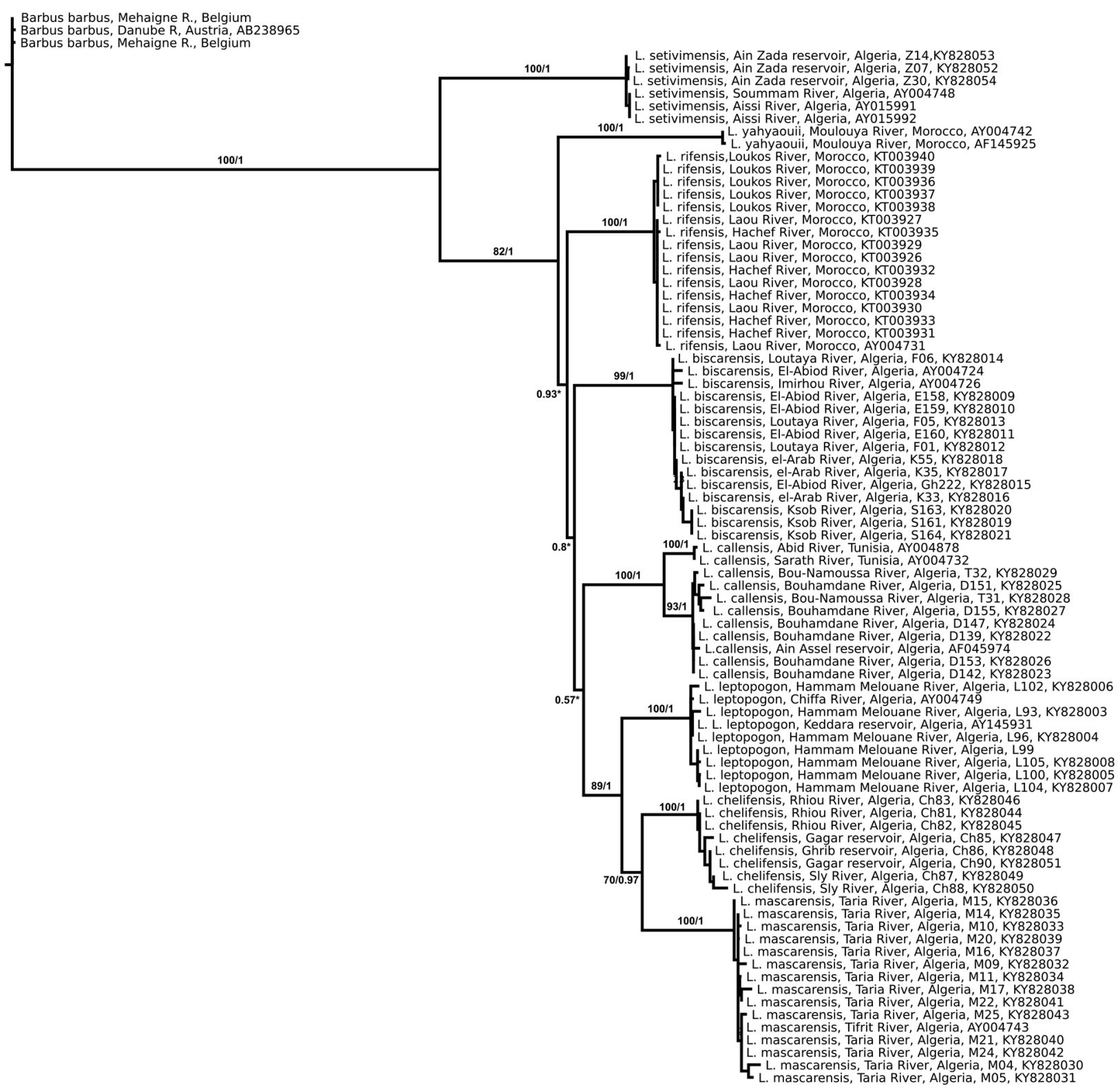

FIGURE 1. Phylogenetic relationships from NAmt (Cyt b and D-loop) of Luciobarbus species from the African Mediterranean basins, using Bayesian inference with posterior probability (PP); numbers left slash correspond to the bootstrap (BT) values. 


\section{Results}

The Bayesian (BI) and the Maximum Likelihood (ML) analysis generated identical topologies in the clades recovered, but did differ in the support for the recovered groups. Luciobarbus biscarensis, L. callensis, $L$. chelifensis, L. leptopogon, L. mascarensis, L. rifensis, L. setivimensis and L. yahyaouii each correspond to one of the molecular groups in our analysis (Fig. 1). Luciobarbus callensis is separated into two groups, indicating, that an additional undescribed species might occur in the east of Algeria. Except for L. setivimensis, the largest molecular distance was found between $L$. yahyaouii and L. chelifensis $(\mathrm{d}=6.3 \%)$ and lowest differentiation between $L$. mascarensis and L. chelifensis $(\mathrm{d}=2.9 \%)$.

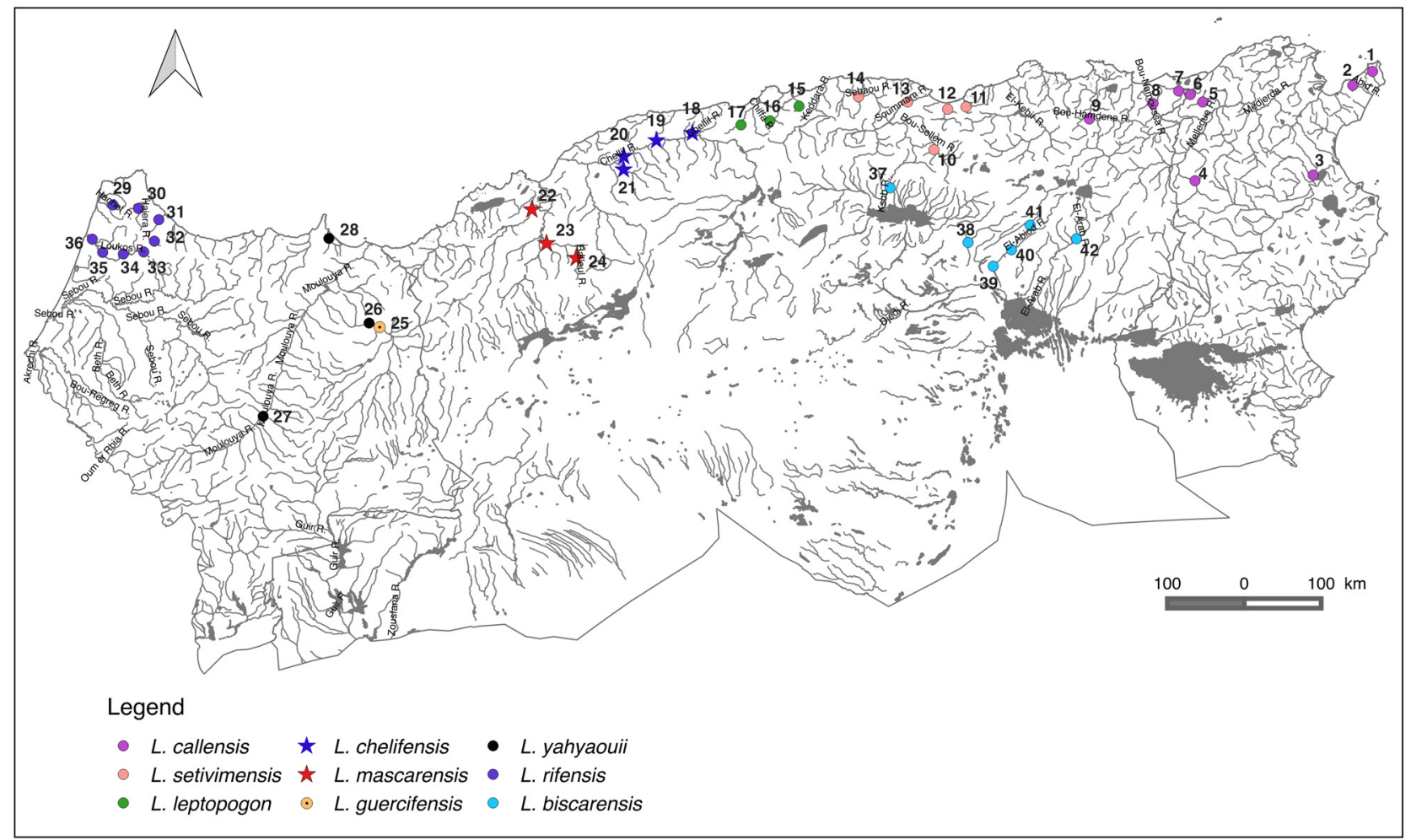

FIGURE 2. Records of Luciobarbus species examined in this study. Numbers correspond to materials examined listed below.

\section{Key to species of Luciobarbus in the African Mediterranean and Sahara basins in Central Algeria and Tunisia}

1a Barbels thick, rostral-barbel origin close to tip of snout. ........................... guercifensis

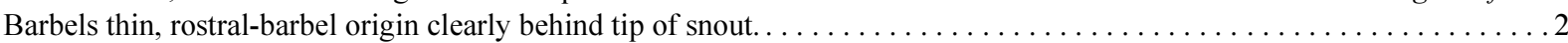
Usually 49-51+1-3 lateral line scales; $7 \frac{1}{2}-8^{1 / 2}$ scale rows below lateral line; dorsal-fin origin behind of vertical of pelvic-fin

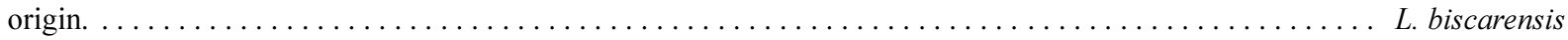
Usually $41-47+1-3$ lateral line scales; $4 \frac{1 / 2-61 / 2}{2}$ scale rows below lateral line; dorsal-fin origin in front or above vertical of pel

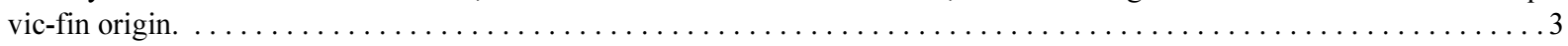
Last unbranched dorsal-fin ray serrated along $2 / 3$ of its length; anal-fin length $19-22 \%$ SL. $\ldots \ldots \ldots \ldots \ldots \ldots \ldots$ Last unbranched dorsal-fin ray serrated along almost its entire length; anal-fin length $16-19 \%$ SL. . . . . . . . . . . .

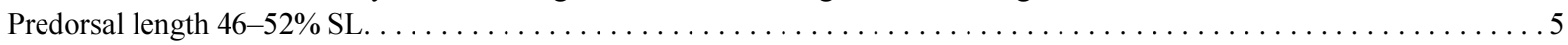

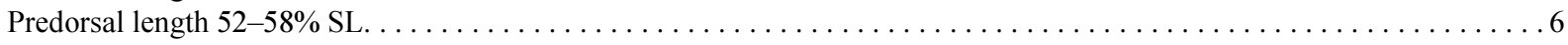
Interorbital distance $36-39 \% \mathrm{HL} ; 41-43+1-2$ lateral line scales. . . . . . . . . . . . . . Luciobarbus leptopogon Interorbital distance $40-44 \%$ HL; 43-47+1-3 lateral line scales. . . . . . . . . . . . . . Luciobarbus setivimensis Distance between pelvic and anal-fin origins 21-24\% SL; caudal peduncle 1.3-1.5 times longer than deep; usually 5, very-

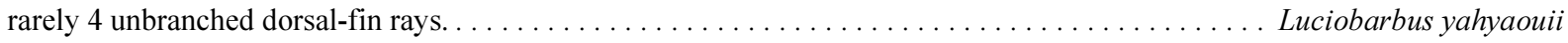
Distance between pelvic and anal-fin origins 24-29\% SL; caudal peduncle 1.2-1.3 times longer than deep; 4 unbranched dor-

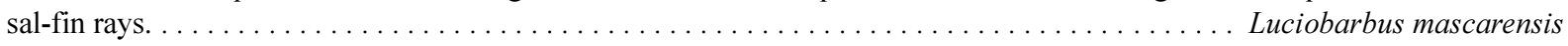
Anal-fin base length $8-10 \%$ SL; $41-43+1-2$ lateral line scales. . . . . . . . . . . . . . . Luciobarbus chelifensis Anal-fin base length 6-8\% SL; 43-47+1-3 lateral line scales. . . . . . . . . . Luciobarbus callensis / Luciobarbus rifensis 


\section{Luciobarbus chelifensis, new species}

(Figs. 3-5)

Holotype. RMCA 2016-024-P-0010, 128 mm SL; Algeria: Chelif prov.: Oued Sly west of Ouled Ben Abdelkader village, $36.026609^{\circ} \mathrm{N} 1.266014^{\circ} \mathrm{E}$; A. Brahimi, 23 Jun 2016.

Paratypes. RMCA 2016-024-P-0011-0016, 6, 102-152 mm SL; same data as holotype.

Material for molecular analyses. RMCA DNA-2016-024-P-Ch81, RMCA DNA-2016-024-P-Ch82, RMCA DNA-2016-024-P-Ch83, Algeria: Relizane prov.: Oued Rhiou at Sidi Abed village, $36.009889^{\circ} \mathrm{N} 0.992520^{\circ} \mathrm{E}$ (GenBank accession numbers: Cyt b: KY828044, KY828045, KY828046; D-loop: KY828098, KY828099, KY828100).- RMCA DNA-2016-024-P-Ch85, RMCA DNA-2016-024-P-Ch90, Algeria: Relizane prov.: Gagar Dam at Ouled Taieb village, $35.908391^{\circ} \mathrm{N} 1.008624^{\circ} \mathrm{E}$ (GenBank accession numbers: Cyt b: KY828047, KY828051; D-loop: KY828101, KY828097).-_RMCA DNA-2016-024-P-Ch87, RMCA DNA-2016-024-P-Ch88, Algeria: Chelif prov.: Oued Sly west of Ouled Ben Abdelkader village, 36.026609 ${ }^{\circ} \mathrm{N} 1.266014^{\circ} \mathrm{E}(\mathrm{GenBank}$ accession numbers: Cyt b: KY828049, KY828050; D-loop: KY828103, KY828096).—RMCA DNA-2016-024-PCh86, Algeria: Ain Defla prov.: Ghrib reservoir at Oued Chorffa, $36.140553^{\circ} \mathrm{N} 2.563226^{\circ} \mathrm{E}$ (GenBank accession numbers: Cyt b: KY828048; D-loop: KY828102).
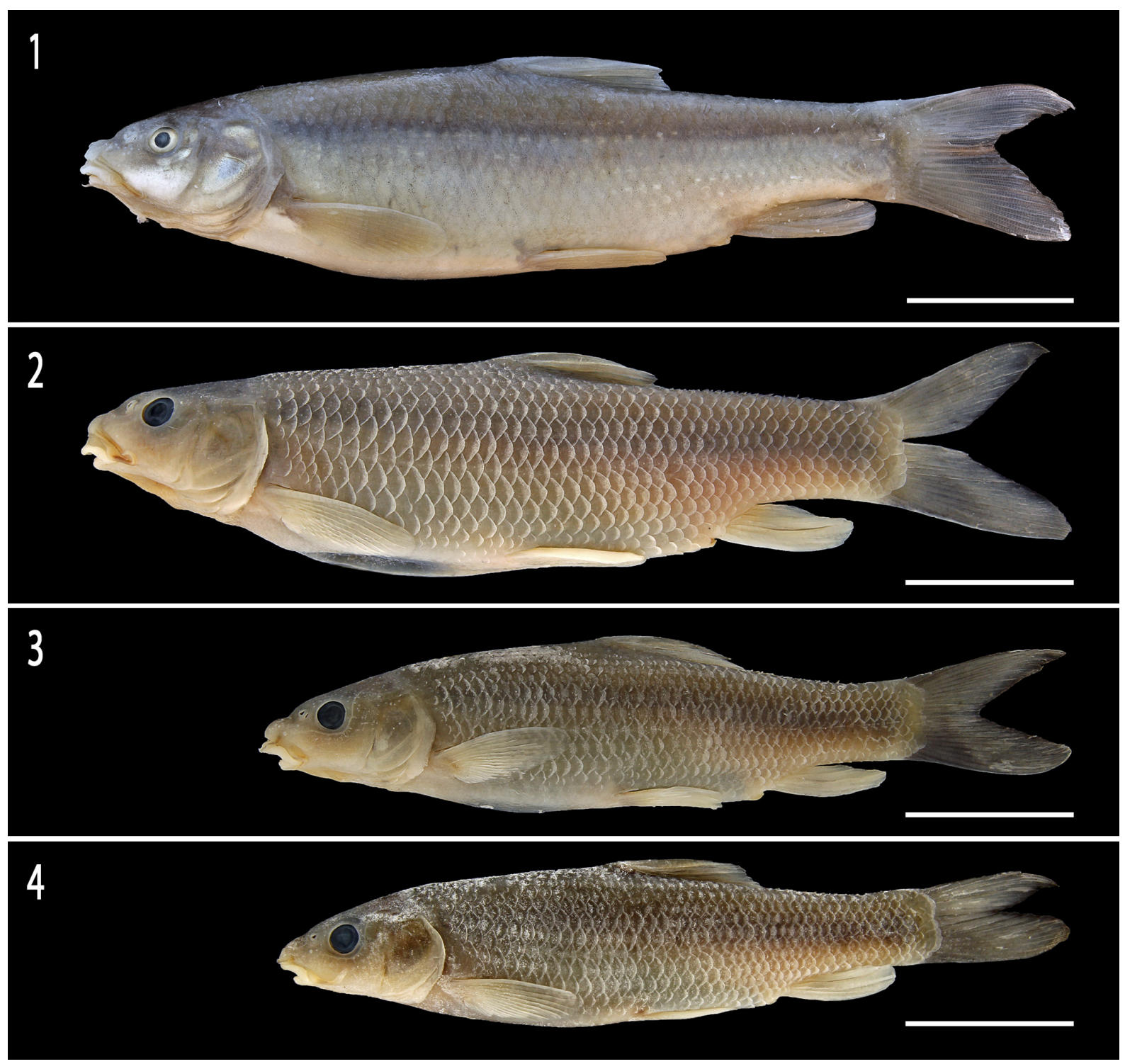

FIGURE 3. Luciobarbus chelifensis, 1, RMCA 2016-024-P-0010, holotype (before preservation), 129 mm SL; 2, RMCA 2016-024-P-0013, paratype, 126 mm SL; 3, RMCA 2016-024-P-0015, paratype, 107 mm SL; 4, RMCA 2016-024-P-0016, paratype, $102 \mathrm{~mm} \mathrm{SL}$; Algeria: Oued Sly west of Ouled Ben Abdelkader. Scale bars $=30 \mathrm{~mm}$. 

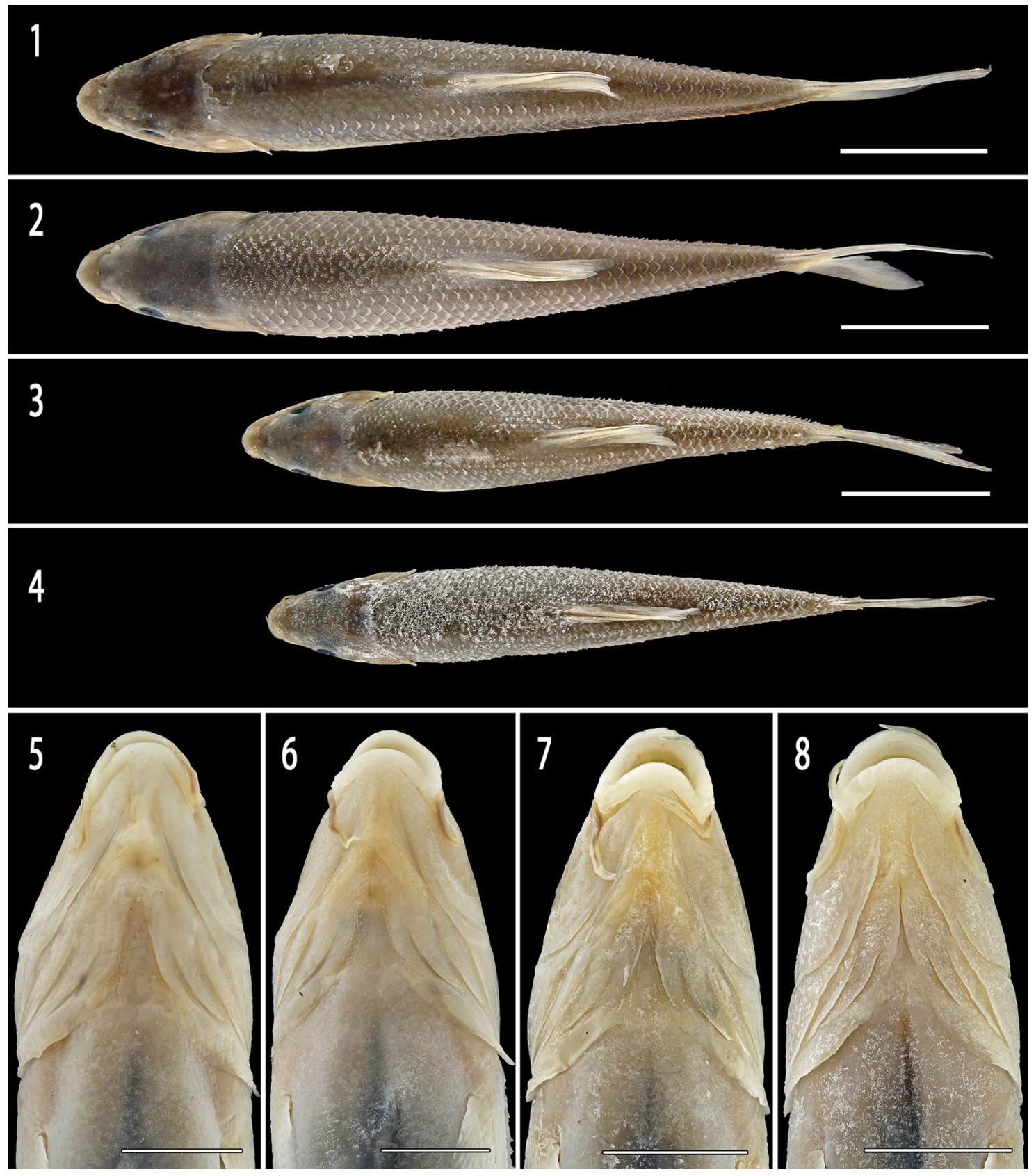

FIGURE 4. Luciobarbus chelifensis, 1+5, RMCA 2016-024-P-0010, holotype, 129 mm SL; 2+6, RMCA 2016-024-P-0013, paratype, $126 \mathrm{~mm} \mathrm{SL;} \mathrm{3+7,} \mathrm{RMCA} \mathrm{2016-024-P-0015,} \mathrm{paratype,} 107 \mathrm{~mm}$ SL; 4+8, RMCA 2016-024-P-0016, paratype, 102 mm SL; Algeria: Oued Sly west of Ouled Ben Abdelkader. Scale bars: $1-4=30 \mathrm{~mm} ; 5-8=10 \mathrm{~mm}$.

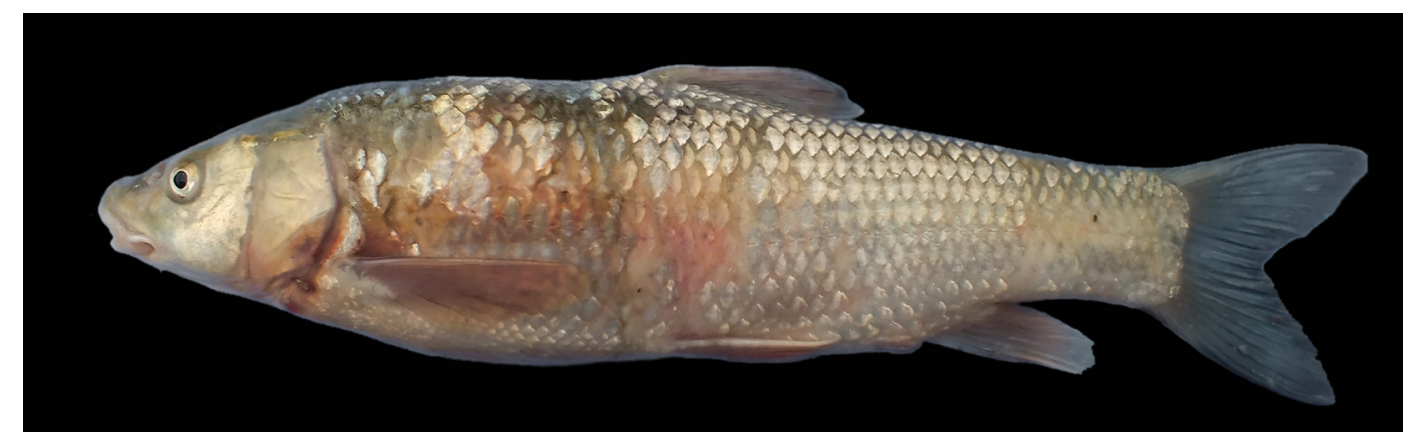

FIGURE 5. Luciobarbus chelifensis, not preserved, about $150 \mathrm{~mm}$ SL; Algeria: Oued Sly west of Ouled Ben Abdelkader. 
TABLE 3. Morphometric data of L. chelifensis (holotype RMCA 2016-024-P-0010; paratypes RMCA 2016-024-P0011-0016, $\mathrm{n}=6$; non-preserved individuals, $\mathrm{n}=19$ ). The holotype is included in the calculation of ranges, means and SD.

\begin{tabular}{|c|c|c|c|c|}
\hline & \multirow[t]{2}{*}{ holotype } & \multicolumn{3}{|c|}{ holotype \& paratypes } \\
\hline & & range & mean & SD \\
\hline Standard length (mm) & 128 & $102-296$ & & \\
\hline \multicolumn{5}{|l|}{ In percent of standard length } \\
\hline Body depth at dorsal-fin origin & 27.3 & $24.8-31.3$ & 27.6 & 1.3 \\
\hline Head length & 24.3 & $22.4-26.4$ & 24.2 & 1.2 \\
\hline Pre-dorsal length & 52.3 & $49-54.2$ & 51.6 & 1.1 \\
\hline Pre-pelvic length & 54.7 & $50.3-56.0$ & 53.4 & 1.6 \\
\hline Pre-anal length & 78.1 & $73.8-79.3$ & 77.3 & 1.6 \\
\hline Dorsal fin base length & 14.1 & $12.8-15.2$ & 13.6 & 0.6 \\
\hline Anal fin base length & 9.4 & $8.5-9.9$ & 9.0 & 0.4 \\
\hline Anal fin length & 18.2 & $17.6-18.5$ & 18.1 & 0.3 \\
\hline Pelvic fin length & 15.6 & $14.1-16.2$ & 15.2 & 0.6 \\
\hline Pectoral fin length & 20.3 & $17.4-20.7$ & 19.0 & 0.9 \\
\hline Caudal peduncle length & 16.4 & $14.0-18.3$ & 15.7 & 1.3 \\
\hline Caudal peduncle depth & 12.2 & $11.2-12.7$ & 11.9 & 0.5 \\
\hline Distance between dorsal and anal-fin origins & 35.2 & $32.9-38.3$ & 35.6 & 1.3 \\
\hline Distance between pectoral and pelvic-fin origins & 29.9 & $25.5-31.3$ & 29.2 & 1.5 \\
\hline Distance between pelvic and anal-fin origins & 23.4 & $20.6-27.6$ & 23.9 & 1.2 \\
\hline \multicolumn{5}{|l|}{ In percent of head length } \\
\hline Snout length & 35.6 & $27-37$ & 32.2 & 2.9 \\
\hline Eye diameter & 15.0 & $14-18$ & 16.3 & 1.0 \\
\hline Post-orbital length & 49.4 & $47-55$ & 51.5 & 2.6 \\
\hline Interorbital distance & 36.7 & $36-40$ & 37.9 & 0.8 \\
\hline Pectoral-fin length & 81.9 & $70-85$ & 78.7 & 4.2 \\
\hline Caudal peduncle depth & 49.1 & $46-52$ & 49.2 & 1.2 \\
\hline
\end{tabular}

Diagnosis. Luciobarbus chelifensis is distinguished from other Luciobarbus species from the African Mediterranean basins by a combination of characters, none of them unique. It is distinguished from all other species, except $L$. leptopogon, by having 41-43+1-2 lateral line scales (vs. 49-51+1-2 in L. biscarensis, 43-47+12 in L. callensis, 43 to 45+1-3 in L. rifensis and L. setivimensis, 42-45+1-2 in L. yahyaouii). The new species also has a very short anal fin (anal-fin length 18-19\% SL vs. 19-22 in L. leptopogon and L. setivimensis, 19-21 in $L$. yahyaouii). Luciobarbus chelifensis is also distinguished from L. leptopogon by having a smaller eye (14-16\% HL vs. 16-20), a greater body depth at the dorsal-fin origin (25-31\% SL vs. 20-27), a shorter pelvic-fin length (14$16 \%$ SL vs. 16-20) and the last unbranched dorsal-fin ray being serrated along almost its entire length (vs. last unbranched dorsal-fin ray serrated along $2 / 3$ of its length). It is further distinguished from L. biscarensis by having 4 unbranched dorsal-fin rays (vs. 5), $7 \frac{1}{2}$ scale rows between the lateral line and the dorsal-fin origin (vs. $8^{1 / 2-9} 1 \frac{1}{2}$ ), $4 \frac{1}{2}-5 \frac{1}{2}$ scale rows between the lateral line and the pelvic-fin origin (vs. $7 \frac{1}{2}-8^{1} \frac{1}{2}$ ) and the dorsal-fin origin being situated above the pelvic-fin origin (vs. behind). Luciobarbus chelifensis is further distinguished from L. callensis and $L$. rifensis by having a wider anal-fin base $(8-10 \%$ SL vs. $5-8$ in $L$. callensis and L. rifensis) and from $L$. setivimensis by the last unbranched ray being serrated along almost its entire length (vs. last unbranched ray serrated along $2 / 3$ of its length) and having a narrower interorbital distance (36-40\% HL vs. $40-44)$. The new species is also distinguished from L. yahyaouii by having always 4 unbranched dorsal-fin rays (vs. usually 5), the last unbranched dorsal-fin ray being serrated along almost its entire length (vs. serrated along $2 / 3$ of its length) and having a shorter pelvic-fin length (14-16\% SL vs. 16-19). 
Description. See Figures 3-5 for general appearance. Morphometric data are given in Table 3 and meristic data are given in Table 5 and 6. A medium-sized species with a moderately long head. Body deepest at dorsal-fin origin or about midline between nape and dorsal-fin origin. Depth decreasing continuously towards caudal-fin base. Greatest body width in front of dorsal-fin base. Caudal peduncle compressed, 1.2-1.5 times longer than deep. Section of head roundish, flattened on ventral surface. Snout rounded. Mouth inferior. Dorsal-fin origin situated above pelvic-fin origin. Anal-fin origin slightly behind vertical of middle between dorsal and caudal-fin origins. Anal fin not reaching caudal-fin base. Pectoral fin reaching approximately $60-75 \%$ of distance from pectoral-fin origin to pelvic-fin origin. Pelvic fin reaching vertical of tip of last dorsal-fin ray when folded down. Pelvic fin reaching to a short distance in front of anus. Posterior dorsal-fin margin straight or slightly convex. Posterior pectoral and anal-fin margins convex. Caudal fin forked with rounded lobes of equal length. Largest known specimen $152 \mathrm{~mm} \mathrm{SL}$, but expected to grow much larger.

Dorsal fin with 4 unbranched and $81 / 2$ branched rays, last unbranched ray serrated along almost its entire length. Anal fin with 3 unbranched and 51/2 branched rays. Pectoral-fin with 15-18 rays (mode 16) and pelvic fin with 7-8 (mode 8) rays. Lateral line with 41-43 scales on flank and 1-2 scales on caudal-fin base. Between dorsal-fin origin and lateral line $7 \frac{1}{2}$ scale rows and $4 \frac{1}{2}-5 \frac{1}{2}$ (mode $4 \frac{1}{2}$ ) scale rows between pelvic-fin origin and lateral line. Pharyngeal teeth in three rows: $4+3+2$.

Coloration. Whitish golden on belly, golden to greenish-grey on flank and back. A wide and indistinct bronze stripe along lateral line. Paired fins and anal fin yellowish or orange. Dorsal and caudal fins grey.

Etymology. Luciobarbus chelifensis is named for the Chelif River. A noun in genitive, indeclinable.

Distribution. Luciobarbus chelifensis was found in the Chelif River drainage in northwestern Algeria. See Figure 2 (18-21) for the distribution of African Mediterranean Luciobarbus species.

\section{Luciobarbus mascarensis, new species}

(Figs. 6-8)

Holotype: RMCA 2016-024-P-0017, $126.1 \mathrm{~mm} \mathrm{SL}$; Algeria: Mascara prov.: Oued Taria north of Meftah Sidi Boubekeur, $35.109848^{\circ} \mathrm{N}, 0.0673^{\circ} \mathrm{E}$; A. Brahimi, A. El-Najar \& M. Kadjame, 1 May 2016.

Paratypes. RMCA 2016-024-P-0018-0026, 9, 66-188 mm SL; same data as holotype.-FSJF 3283, 4, 75-121 mm SL; Algeria: Oued el Hammam upriver of Hacine, $35.444265^{\circ} \mathrm{N} 0.035043^{\circ} \mathrm{E}$.

Material for molecular analyses. RMCA DNA-2016-024-P-M09-M22; Algeria: Mascara prov.: Oued Taria north of Meftah Sidi Boubekeur, $35.109848^{\circ} \mathrm{N}, 0.0673^{\circ} \mathrm{E}$ (GenBank accession numbers: Cyt b: KY828030, KY828031, KY828032, KY828033, KY828034, KY828035, KY828036, KY828037, KY828038, KY828039, KY828040, KY828041, KY828042, KY828043; D-loop: KY828082, KY828083, KY828084, KY828085, KY828086, KY828087, KY828088, KY828089, KY828090, KY828091, KY828092, KY828093, KY828094, KY828095).

Diagnosis. Luciobarbus mascarensis is distinguished from other Luciobarbus species from the African Mediterranean basin except $L$. chelifensis and L. leptopogon, by having usually 41+1-2 lateral line scales (vs. 4951+1-2 in L. biscarensis, 43-47+1-2 in L. callensis, 43-45+1-3 in L. rifensis and L. setivimensis, 42-45+1-2 in $L$. yahyaouii) (Table 6). Only L. chelifensis and L. leptopogon have regularly 41 lateral-line scales on the flank. Luciobarbus mascarensis is distinguished from $L$. chelifensis by having a longer anal-fin (19-22\% SL vs. 18-19) and the dorsal fin serrated at 2/3 of its length (vs. serrated along almost its entire length) and from L. leptopogon by having a deeper body (body depth at dorsal-fin origin $26-31 \%$ SL vs. 20-27) and a wider caudal peduncle (caudal peduncle depth 74-84\% caudal peduncle length vs. 60-74). Luciobarbus mascarensis is also distinguished from $L$. biscarensis by having $7 \frac{1}{2}$ scale rows between the lateral line and the dorsal-fin origin (vs. $\left.8^{1 / 2}-9 \frac{1}{2}\right), 4 \frac{1}{2}-5 \frac{1}{2}$ scale rows between the lateral line and the pelvic-fin origin (vs. $7 \frac{1}{2}-8 \frac{1}{2}$ ), 4 unbranched dorsal-fin rays (vs. 5), the dorsalfin origin situated in front or above the pelvic-fin origin (vs. behind), a longer anal-fin (19-22\% SL vs. 17-20), a short caudal peduncle (caudal peduncle length $15-17 \%$ SL vs. 16-19). It is further distinguished from L. callensis and $L$. rifensis by having a longer anal-fin (19-22\% SL vs. 17-19 in L callensis, 16-19 in L. rifensis), a wider analfin base (7-10\% SL vs. $6-8$ in L. rifensis) and a wider caudal peduncle (caudal peduncle depth $74-84 \%$ caudal peduncle length vs. 60-78 in L. rifensis). Luciobarbus mascarensis is also distinguished from L. setivimensis by having a more narrow interorbital distance (36-40\% HL vs. 40-44). The new species is also distinguished from $L$. 
yahyaouii by having 4 unbranched dorsal-fin rays (vs. usually 5), a greater distance between the pelvic and anal-fin origins (24-28\% SL vs. 21-24) and a shorter caudal peduncle (caudal peduncle length 15-17\% SL vs. 16-19.4).
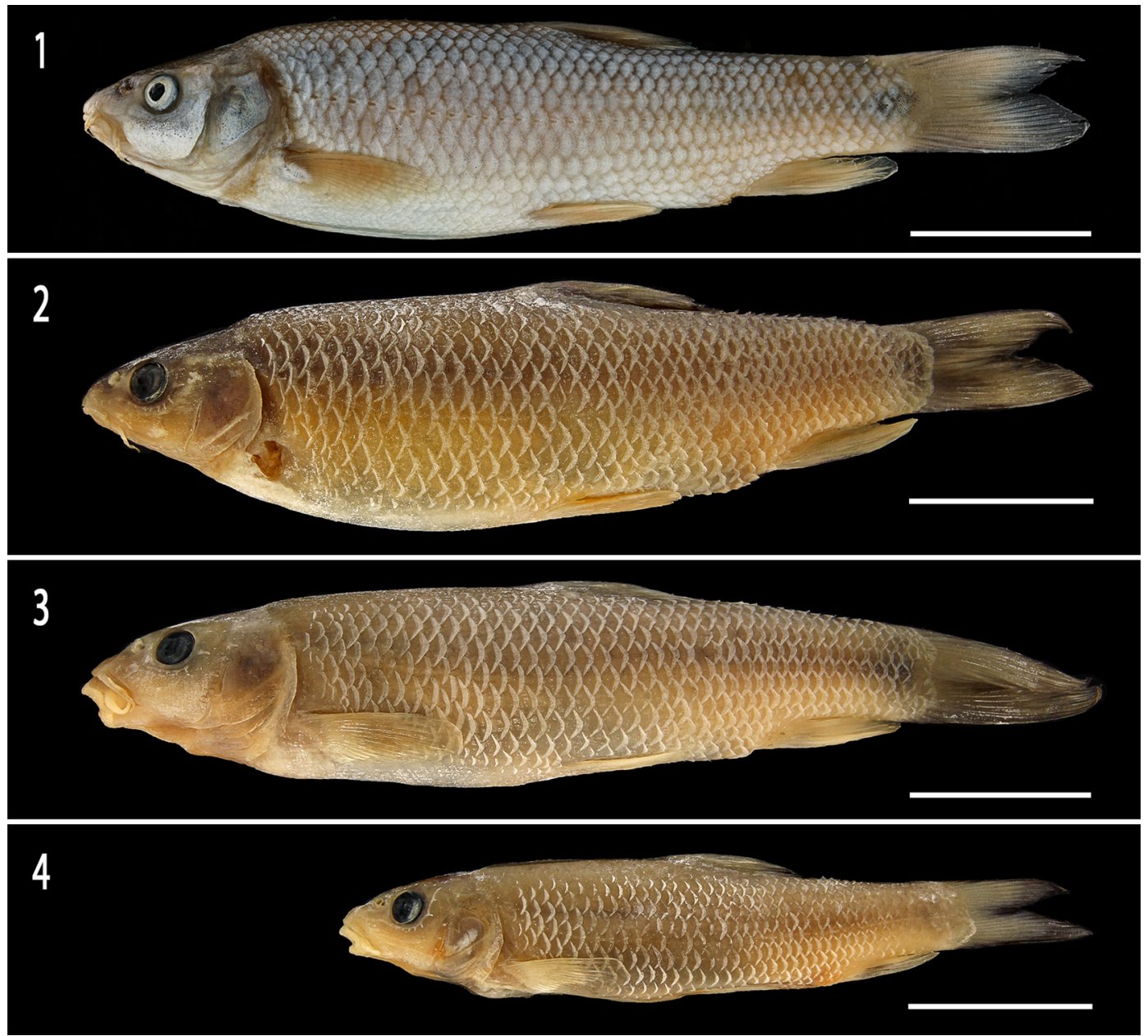

FIGURE 6. Luciobarbus mascarensis, 1, RMCA 2016-024-P-0017, holotype (before preservation), 129 mm SL; 2, RMCA 2016-024-P-0021, paratype, 123 mm SL; 3, RMCA 2016-024-P-0024, paratype, 120 mm SL; 4, RMCA 2016-024-P-0025, paratype, $93 \mathrm{~mm}$ SL; Algeria: Oued Taria north of Meftah Sidi Boubekeur. Scale bars $=30 \mathrm{~mm}$.

TABLE 6. Frequencies of lateral-line scales on flank in Luciobarbus species examined for this study.

\begin{tabular}{|c|c|c|c|c|c|c|c|c|c|c|c|c|}
\hline \multirow[t]{2}{*}{ Species } & \multirow[t]{2}{*}{$\mathrm{N}$} & \multicolumn{11}{|c|}{ Scales on the lateral line } \\
\hline & & 41 & 42 & 43 & 44 & 45 & 46 & 47 & 48 & 49 & 50 & 51 \\
\hline L. biscarensis & 26 & & & & & & & & & 8 & 2 & 16 \\
\hline L. callensis & 34 & & & 2 & 5 & 16 & 9 & 2 & & & & \\
\hline L. chelifensis & 15 & 4 & 9 & 2 & & & & & & & & \\
\hline L. leptopogon & 18 & 5 & 8 & 5 & & & & & & & & \\
\hline L.mascarensis & 15 & 14 & & 1 & & & & & & & & \\
\hline L. rifensis & 19 & & & 10 & 6 & 3 & & & & & & \\
\hline L. setivimensis & 30 & & & 6 & 9 & 5 & 8 & 2 & & & & \\
\hline L. yahyaouii & 19 & & 6 & 7 & 4 & 2 & & & & & & \\
\hline
\end{tabular}

Description. See Figures 6-8 for general appearance. Morphometric data are given in Table 4 and meristic data are given in Table 5 and 6 . Middle sized and stout species, with a moderately long head. Dorsal profile with a well-marked discontinuity between head and back. Body deepest at about midline between nape and dorsal-fin origin. Depth decreasing continuously towards caudal-fin base. Greatest body width between pectoral and dorsal- 
fin origins. Caudal peduncle compressed, 1.2-1.3 times longer than its deep. Section of head roundish, flattened on ventral surface. Snout blunt. Mouth inferior. Dorsal-fin origin in front or almost above pelvic-fin origin. Anal-fin origin slightly behind vertical of middle between dorsal and caudal-fin origins. Anal fin reaching to caudal-fin base. Pectoral fin reaching approximately $59-77 \%$ of distance between pectoral-fin origin and pelvic-fin origin. Pelvic fin not reaching vertical of tip of last dorsal-fin ray when folded down. Pelvic fin reaching to a short distance in front of anus. Posterior dorsal-fin margin straight or slightly convex. Posterior pectoral-fin margin convex. Posterior anal-fin margin convex. Caudal fin forked with rounded lobes of equal size. Largest known specimen 140 $\mathrm{mm}$ SL, but expected to grow much larger.
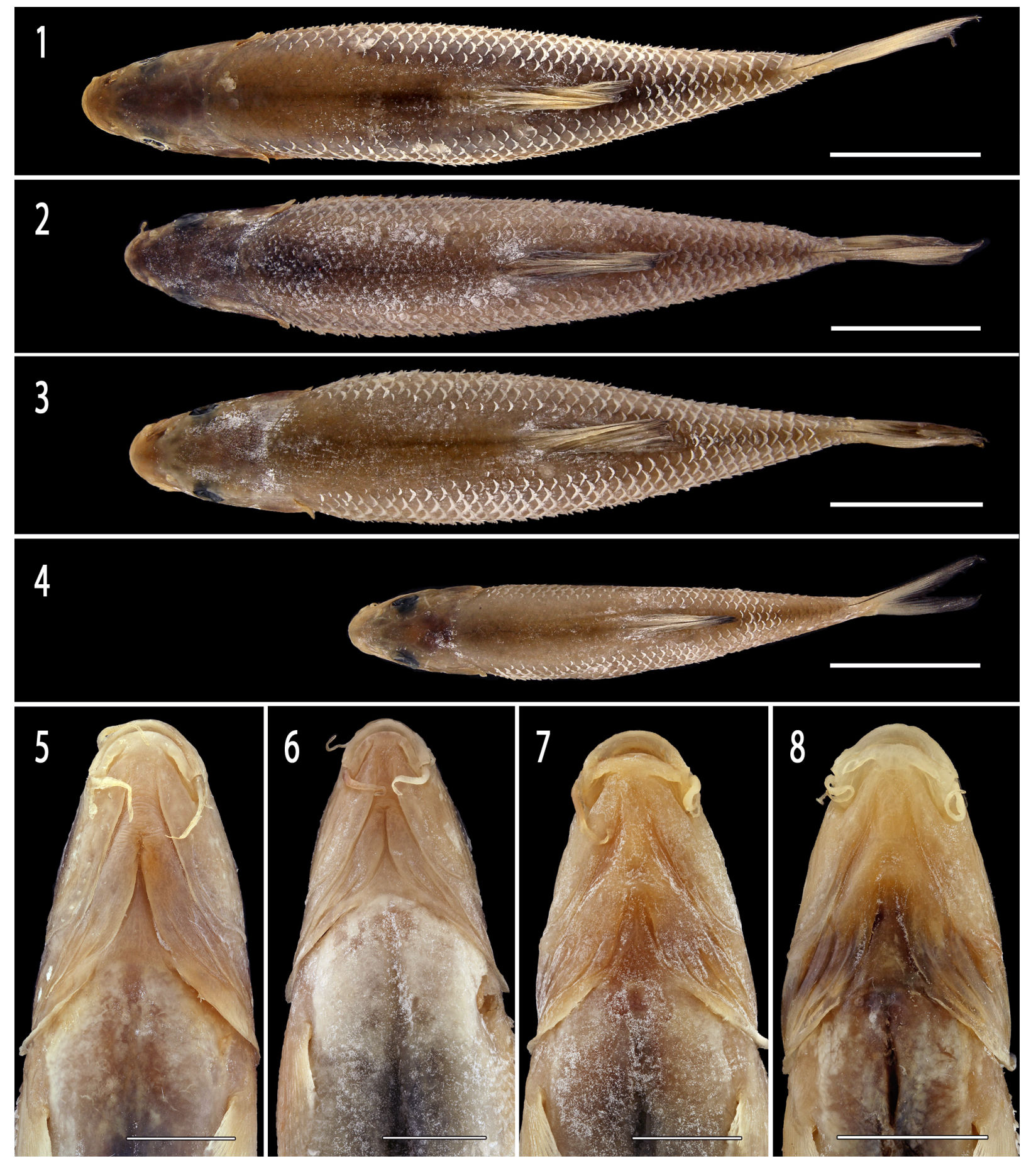

FIGURE 7. Luciobarbus mascarensis, 1+5, RMCA 2016-024-P-0017, holotype (before preservation), 129 mm SL; 2+6, RMCA 2016-024-P-0021, paratype, 123 mm SL; 3+7, RMCA 2016-024-P-0024, paratype, 120 mm SL; 4+8, RMCA 2016024-P-0025, paratype, $93 \mathrm{~mm}$ SL; Algeria: Oued Taria north of Meftah Sidi Boubekeur. Scale bars: $1-4=30 \mathrm{~mm}$; 5-8 = 10 $\mathrm{mm}$. 
TABLE 4. Morphometric data of L. mascarensis (holotype RMCA 2016-024-P-0017; paratypes RMCA 2016-024-P0018-0026, $\mathrm{n}=9$; non-preserved individuals, $\mathrm{n}=15$ ). The holotype and paratypes are included in the calculation of ranges, means and SD.

\begin{tabular}{|c|c|c|c|c|}
\hline & \multirow[t]{2}{*}{ holotype } & \multicolumn{3}{|c|}{ holotype \& paratypes } \\
\hline & & range & mean & SD \\
\hline Standard length (mm) & 126.1 & $63.5-185$ & & \\
\hline \multicolumn{5}{|l|}{ In percent of standard length } \\
\hline Body depth at dorsal-fin origin & 26.2 & $26.2-30.6$ & 28.6 & 1.1 \\
\hline Head length & 25.8 & $24.4-28.0$ & 26.1 & 0.8 \\
\hline Pre-dorsal length & 54.7 & $52.5-58.3$ & 54.6 & 1.4 \\
\hline Pre-pelvic length & 54.9 & $50.0-58.3$ & 54.4 & 1.7 \\
\hline Pre-anal length & 80.9 & $73.3-85.1$ & 79.9 & 1.9 \\
\hline Dorsal fin base length & 12.4 & $12.1-15.3$ & 13.8 & 0.8 \\
\hline Anal fin base length & 7.5 & $6.6-9.6$ & 7.9 & 0.6 \\
\hline Anal fin length & 19.7 & $19.1-21.7$ & 20.1 & 0.7 \\
\hline Pelvic fin length & 16.0 & $14.3-19.4$ & 15.8 & 1.2 \\
\hline Pectoral fin length & 18.7 & $16.4-21.3$ & 18.5 & 1.3 \\
\hline Caudal peduncle length & 15.8 & $15.2-17.1$ & 16.3 & 0.5 \\
\hline Caudal peduncle depth & 11.8 & $11.8-13.3$ & 12.6 & 0.4 \\
\hline Distance between dorsal and anal-fin origins & 34.9 & $32.8-38.1$ & 34.9 & 1.3 \\
\hline Distance between pectoral and pelvic-fin origins & 34.9 & $25.8-31.4$ & 28.3 & 1.4 \\
\hline Distance between pelvic and anal-fin origins & 27.0 & $24.1-28.2$ & 25.6 & 1.2 \\
\hline \multicolumn{5}{|l|}{ In percent of head length } \\
\hline Snout length & 31.8 & $26-38$ & 32.3 & 2.8 \\
\hline Eye diameter & 21.3 & $15-28$ & 21.8 & 2.7 \\
\hline Post-orbital length & 46.9 & $44-48$ & 45.9 & 0.7 \\
\hline Interorbital distance & 39.7 & $36-40$ & 38.8 & 0.8 \\
\hline Pectoral-fin length & 72.5 & $61-80$ & 70.8 & 5.2 \\
\hline Caudal peduncle depth & 45.8 & $46-53$ & 48.5 & 1.2 \\
\hline
\end{tabular}

TABLE 5. Frequencies of meristic characters: unbranched dorsal-fin rays and branched fin rays of Luciobarbus species examined for this study.

\begin{tabular}{|c|c|c|c|c|c|c|c|c|c|c|}
\hline \multirow[t]{2}{*}{ Species } & \multirow[t]{2}{*}{$\mathrm{N}$} & \multicolumn{3}{|c|}{ unbranched dorsal-fin rays } & \multirow[t]{2}{*}{$\mathrm{N}$} & \multicolumn{3}{|c|}{ branched dorsal-fin rays } & \multicolumn{2}{|c|}{ branched pelvic-fin rays } \\
\hline & & 3 & 4 & 5 & & $71 / 2$ & $81 / 2$ & $91 / 2$ & 7 & 8 \\
\hline L. biscarensis & 26 & & & 26 & 64 & 5 & 59 & & 22 & 42 \\
\hline L. callensis & 34 & & 19 & 4 & 60 & & 60 & & & 60 \\
\hline L. chelifensis & 15 & & 15 & & 26 & & 26 & & 2 & 24 \\
\hline L. leptopogon & 18 & & 18 & & 39 & & 39 & & 1 & 38 \\
\hline L.mascarensis & 15 & & 13 & & 29 & & 29 & & 5 & 24 \\
\hline L. rifensis & 19 & & 13 & 6 & 19 & & 19 & & & 19 \\
\hline L. setivimensis & 30 & 8 & 22 & & 57 & & 57 & & 4 & 53 \\
\hline L. yahyaouii & 19 & & 1 & 18 & 29 & & 27 & 2 & 4 & 25 \\
\hline
\end{tabular}

Dorsal fin with 4 unbranched and $8 \frac{1}{2}$ branched rays, last unbranched ray ossified and serrated at 2/3 of its length. Anal fin with 3 unbranched and 51/2 branched rays. Pectoral-fin with 13-16 (mode 15) and pelvic fin with 7-8 (mode 8) rays. Lateral line with $41(n=14)$ and $43(n=1)$ scales on flank and 1-2 scales on caudal-fin base. 
Between dorsal-fin origin and lateral line $7 \frac{1}{2}$ scale rows and $4 \frac{1}{2}-51 / 2$ (mode $5 \frac{1}{2}$ ) scale rows between pelvic-fin origin and lateral line. Pharyngeal teeth in three rows: $4+3+2$.

Coloration. Body yellowish brown in life and preserved individuals without colour pattern. Head plain brown, cheeks and ventral head and body whitish. Fins hyaline, usually with yellowish rays.

Etymology. Luciobarbus mascarensis is named for the Mascara region in western Algeria. A noun in genitive, indeclinable.

Distribution. Luciobarbus mascarensis was found in streams in the Macta River drainage in northwestern Algeria. See Figure 2 (22-24) for the distribution of African Mediterranean Luciobarbus species.

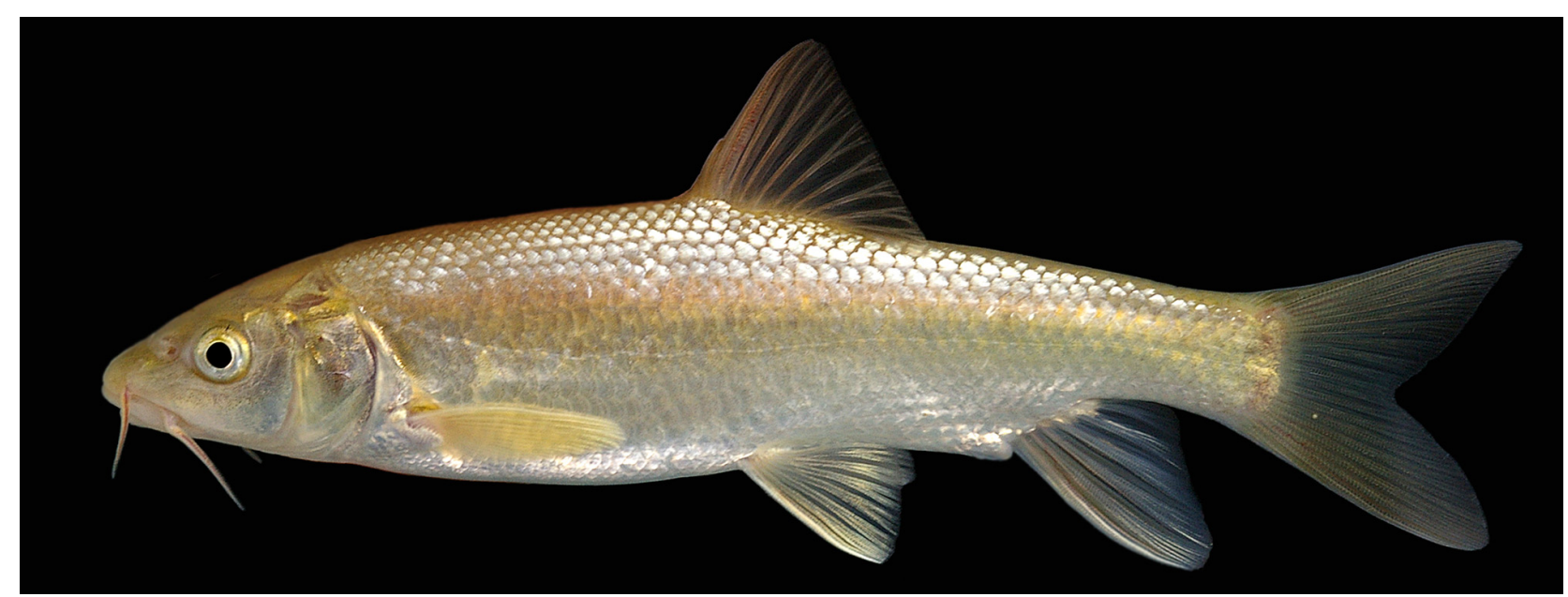

FIGURE 8. Luciobarbus mascarensis, FSJF 3283, 121 mm SL; Algeria: Oued el Hammam upriver of Hacine.

\section{Discusssion}

While we made considerable efforts to detect external morphological characters usable to identify the different Luciobarbus species from the African Mediterranean basin, we found this exercise frustrating. Most species are very similar in their morphometric and meristic characters and almost all morphometric and meristic ranges overlap and larger overlaps are expected, if larger series of specimens would be examined. Only L. guercifensis and $L$. biscarensis are well distinguished from the other species. We found no character to distinguish $L$ rifensis from $L$. callensis and both might be real cryptic species. Casal-Lopez et al. (2015) and Doadrio et al. (2016a, 2016b) also found very few morphological characters to distinguish their new species and they base their diagnosis largely on molecular characters. With regard to the paucity of morphological characters, the inclusion of molecular genetic characters into standard taxonomic works in Luciobarbus is of great value.

The literature is full of studies, where molecular trees and morphological species do not fit together (see for example Astrin et al. 2012 and citations herein). Molecular characters, or more correctly molecular distances, must be handeled with great care in taxonomy as there are no agreed molecular distances for species level deliniations. That means, that "little" of "great" molecular distances are not defined and there is no "species level distance". Naturally, the same is true for morphological characters, which need a certain experience in handling.

Many authors failed to find the so called "barcode-gap"', especially if young and allopatric species are involved (see Geiger et al. 2014 for an example of freshwater fishes). While there is a trend to reject morphologically "well" distinguished species in the case of "little" molecular distances, the term cryptic species is misused to name molecular lineages as own species without appropriate morphological comparative studies. Great care has to be taken and we should allow certain molecular differences between populations of geographically widely distributed species occuring in obvioulsy isolated populations. While this is not the place to discuss this topic in depth, we ask for great care not to describe each population making a slighly different clade in a phylogenetic tree as a different, cryptic, species. Such cases are within the greyzone between species and populations and need wise treatments. Recognising, usually young species which are morphologically "well" distinguished but show "little" molecular differences should not open the door to describe just all populations with little molecular differences, also those lacking morphological differences, as cryptic species. 
TABLE 7. Morphometric data of L. biscarensis (FSJF 3286, $\mathrm{n}=31$; FSJF 3279, $\mathrm{n}=9$; non-preserved individuals, $\mathrm{n}=24$ ); L. callensis (FSJF 3014, $\mathrm{n}=6$; FSJF 3011, $\mathrm{n}=4$; FSJF 3017, $\mathrm{n}=20$; FSJF 3008, $\mathrm{n}=9$; non-preserved individuals, $\mathrm{n}=21$ ); $L$ leptopogon (FSJF 3284, n=9; RMCA-2016-024-P-0001-0009: $\mathrm{n}=9$; non-preserved individuals, $\mathrm{n}=21$ ).

\begin{tabular}{|c|c|c|c|c|c|c|c|c|c|}
\hline & \multicolumn{3}{|c|}{ L. biscarensis } & \multicolumn{3}{|l|}{ L. callensis } & \multicolumn{3}{|c|}{ L. leptopogon } \\
\hline & range & mean & SD & range & mean & SD & range & mean & SD \\
\hline Standard length $(\mathrm{mm})$ & $50-305$ & & & 44-334 & & & $76-175$ & & \\
\hline \multicolumn{10}{|l|}{ In percent of standard length } \\
\hline Body depth at dorsal-fin origin & $21.1-28.8$ & 25.3 & 2.0 & $22.0-30.9$ & 26.5 & 2.3 & $20.2-27.0$ & 24.4 & 2.0 \\
\hline Head length & $25.5-28.8$ & 26.8 & 0.7 & $24.3-29.8$ & 26.4 & 1.2 & $23.9-28.3$ & 25.9 & 0.7 \\
\hline Pre-dorsal length & $51.9-57.4$ & 54.4 & 1.2 & $49.4-55.2$ & 52.0 & 1.3 & $48.8-52.6$ & 51.1 & 0.9 \\
\hline Pre-pelvic length & $50.0-56.5$ & 54.3 & 1.4 & $50.6-56.9$ & 53.0 & 1.3 & $51.1-57.1$ & 54.1 & 1.4 \\
\hline Pre-anal length & $73.0-81.2$ & 77.2 & 1.9 & $73.5-81.4$ & 77.1 & 1.7 & $73.6-81.6$ & 78.1 & 2.2 \\
\hline Dorsal fin base length & $11.3-15.4$ & 13.3 & 1.0 & $12.1-15.8$ & 13.9 & 0.9 & $13.9-15.8$ & 14.6 & 0.6 \\
\hline Anal fin base length & $6.0-8.6$ & 7.5 & 0.5 & $6.5-8.4$ & 7.3 & 0.5 & $6.8-10.2$ & 8.4 & 1.0 \\
\hline Anal fin length & $17.3-20.0$ & 18.7 & 0.6 & $16.9-19.0$ & 17.9 & 0.4 & $19.3-21.9$ & 20.5 & 0.6 \\
\hline Pelvic fin length & $12.3-17.8$ & 15.3 & 1.3 & $13.9-20.5$ & 16.4 & 1.5 & $16.3-20.0$ & 17.8 & 1.1 \\
\hline Pectoral fin length & $16.1-21.2$ & 18.3 & 1.1 & $17.7-23.1$ & 20.4 & 1.2 & $17.9-22.9$ & 20.2 & 1.3 \\
\hline Caudal peduncle length & $16.5-19.3$ & 17.6 & 0.7 & $15.1-20.5$ & 17.3 & 0.9 & $15.0-19.5$ & 17.3 & 1.0 \\
\hline Caudal peduncle depth & $11,0-13.3$ & 11.8 & 0.7 & $11.0-14.1$ & 12.6 & 0.5 & $10.5-12.9$ & 11.8 & 0.5 \\
\hline $\begin{array}{l}\text { Distance between dorsal and } \\
\text { anal-fin origins }\end{array}$ & $27.3-36.4$ & 31.3 & 2.0 & $29.7-39.3$ & 34.4 & 1.7 & $30.1-38.2$ & 33.7 & 1.7 \\
\hline $\begin{array}{l}\text { Distance between pectoral and } \\
\text { pelvic-fin origins }\end{array}$ & $21.8-30.2$ & 27.4 & 1.6 & $22.5-29.3$ & 26.6 & 1.4 & $25.6-31.2$ & 28.2 & 1.6 \\
\hline $\begin{array}{l}\text { Distance between pelvic and } \\
\text { anal-fin origins }\end{array}$ & $19.0-27.1$ & 23.0 & 1.7 & $20.4-27.7$ & 24.1 & 1.7 & $20.6-26.9$ & 24.0 & 1.6 \\
\hline \multicolumn{10}{|l|}{ In percent of head length } \\
\hline Snout length & $30-39$ & 34.5 & 2.2 & $24-41$ & 33.8 & 4.8 & $29-34$ & 32.1 & 1.2 \\
\hline Eye diameter & $9-21$ & 15.6 & 4.0 & $11-28$ & 16.6 & 5.0 & $17-24$ & 20.6 & 1.5 \\
\hline Post-orbital length & $44-53$ & 49.9 & 2.7 & $44-50$ & 47.6 & 1.0 & $45-50$ & 47.4 & 0.9 \\
\hline Interorbital distance & $31-39$ & 35.5 & 1.9 & $32-42$ & 36.9 & 1.9 & $36-39$ & 38.0 & 0.9 \\
\hline Pectoral-fin length & $61-78$ & 68.2 & 4.1 & 69-84 & 77.2 & 3.3 & $63-90$ & 78.0 & 5.7 \\
\hline Caudal peduncle depth & $41-47$ & 43.8 & 1.7 & $40-53$ & 47.8 & 2.8 & $41-59$ & 45.7 & 2.1 \\
\hline
\end{tabular}

\section{Comparative material}

\section{Numbers in brackets correspond to Figure 2.}

Luciobarbus biscarensis: FSJF 3286, 31, 69-190 mm SL; Algeria: Biskra prov.: Oued el Abiod above damlake

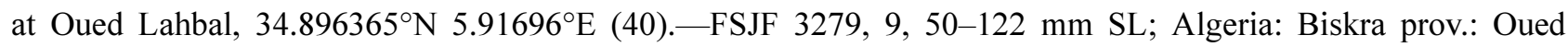
Loutaya at Manbae, $35.094477^{\circ} \mathrm{N} 5.586152^{\circ} \mathrm{E}(38)$.

Luciobarbus callensis. FSJF 3014, 6, 35-97 mm SL; Tunisia: Oued el Abid about 2 km west of Erritiba, $36.867286^{\circ} \mathrm{N} 10.724574^{\circ} \mathrm{E}(2)$. - FSJF 3011, 4, 36-94 mm SL; Tunisia: Oued Ghezala $1 \mathrm{~km}$ south of Fernana, $36.643868^{\circ} \mathrm{N} 8.699214^{\circ} \mathrm{E}(5)$. - FSJF 3017, 20, 60-210 mm SL; Tunisia: Kébir River below Zouitina reservoir, $36.732208^{\circ} \mathrm{N} 8.529498^{\circ} \mathrm{E}$ (6).-FSJF 3008, 9, 71-145 mm SL; Tunisia: Oued Zahzah $2 \mathrm{~km}$ south of Bechechema, $35.821259^{\circ} \mathrm{N} 10.159296^{\circ} \mathrm{E}(3)$.

Luciobarbus leptopogon: FSJF 3284, 9, 97-128 mm SL; Algeria: stream Meliji at Hammam Melouane, 36.489275 $\mathrm{N} 3.050077^{\circ} \mathrm{E}$ (15).- RMCA-2016-024-P-0001-0009: 9, 76-133 mm SL; Algeria: Blida prov.: Oued Hammam Melouane, $36.4829^{\circ} \mathrm{N}, 3.0414^{\circ} \mathrm{E}(16)$. 
Luciobarbus mascarensis: FSJF 3283, 4, 74-121 mm SL; Algeria: Oued el Hammam upriver of Hacine, $35.444265^{\circ} \mathrm{N} 0.035043^{\circ} \mathrm{E}(22)$.

Luciobarbus rifensis: FSJF 3335, 19, 80-208 mm SL; Morocco: Laou River near Chefchaouene, $35.168483^{\circ} \mathrm{N}$ $5.314508^{\circ} \mathrm{W}(31-32)$.

Luciobarbus setivimensis: FSJF 3289, 15, 66-156 mm SL; Algeria: Oued Zitouna at Tala Khaled, $36.634327^{\circ} \mathrm{N} 5.216879^{\circ} \mathrm{E}(12) .-\mathrm{FSJF} 3297,13,132-225 \mathrm{~mm} \mathrm{SL}$; Algeria: Oued Boughzazene at Boughzazene, $36.614407^{\circ} \mathrm{N} 5.361913^{\circ} \mathrm{E}(11) .-\mathrm{FSJF} 3292,19,66-156 \mathrm{~mm}$ SL; Algeria: Oued Remila at inflow into Oued Soummam, $36.632246^{\circ} \mathrm{N} 4.74745^{\circ} \mathrm{E}(13)$.

Luciobarbus yahyaouii: FSJF 3331, 10, 75-166 mm SL; Morocco, Mar chica, Small wadi on road to Kariat Arkmane, $35.052146^{\circ} \mathrm{N}-2.876565^{\circ} \mathrm{W}$ (28).-FSJF 3313, 19, 67-187 mm SL; Morocco: Oued Za near Guefait, Moulouya, $34.226706^{\circ} \mathrm{N} 2.392343^{\circ} \mathrm{W}(29)$.

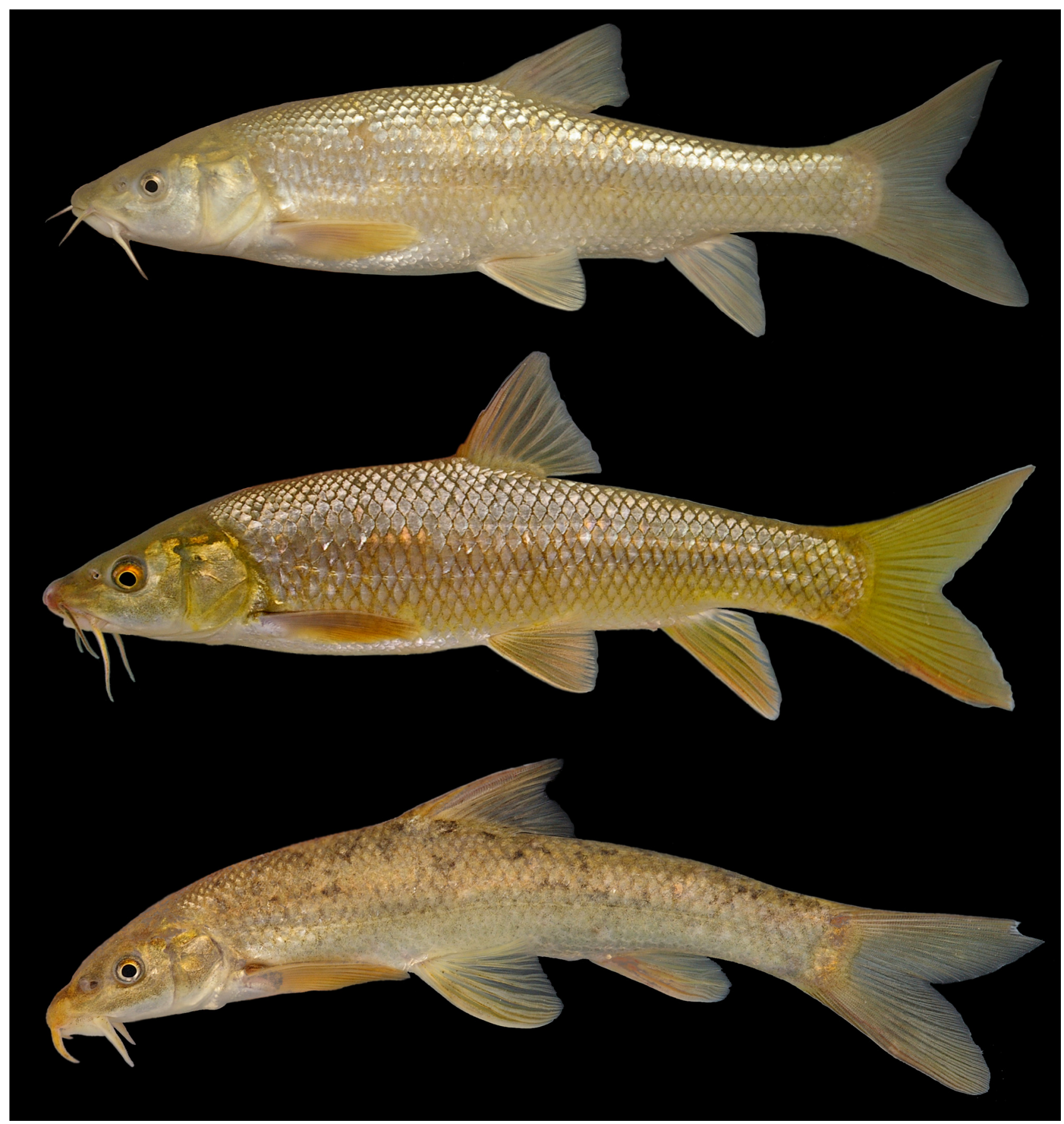

FIGURE 9. Luciobarbus species from the African Mediterranean basin. From the top. Luciobarbus biscariensis, not preserved, 300 mm SL; Algeria: Oued El-Aboid above reservoir; Luciobarbus callensis, FSJF 3017, 250 mm SL; Tunisia: river below Zouitina reservoir; Luciobarbus guercifensis, FSJF 3311, 140 mm SL; Morocco: Oued Za near Guefaït. 


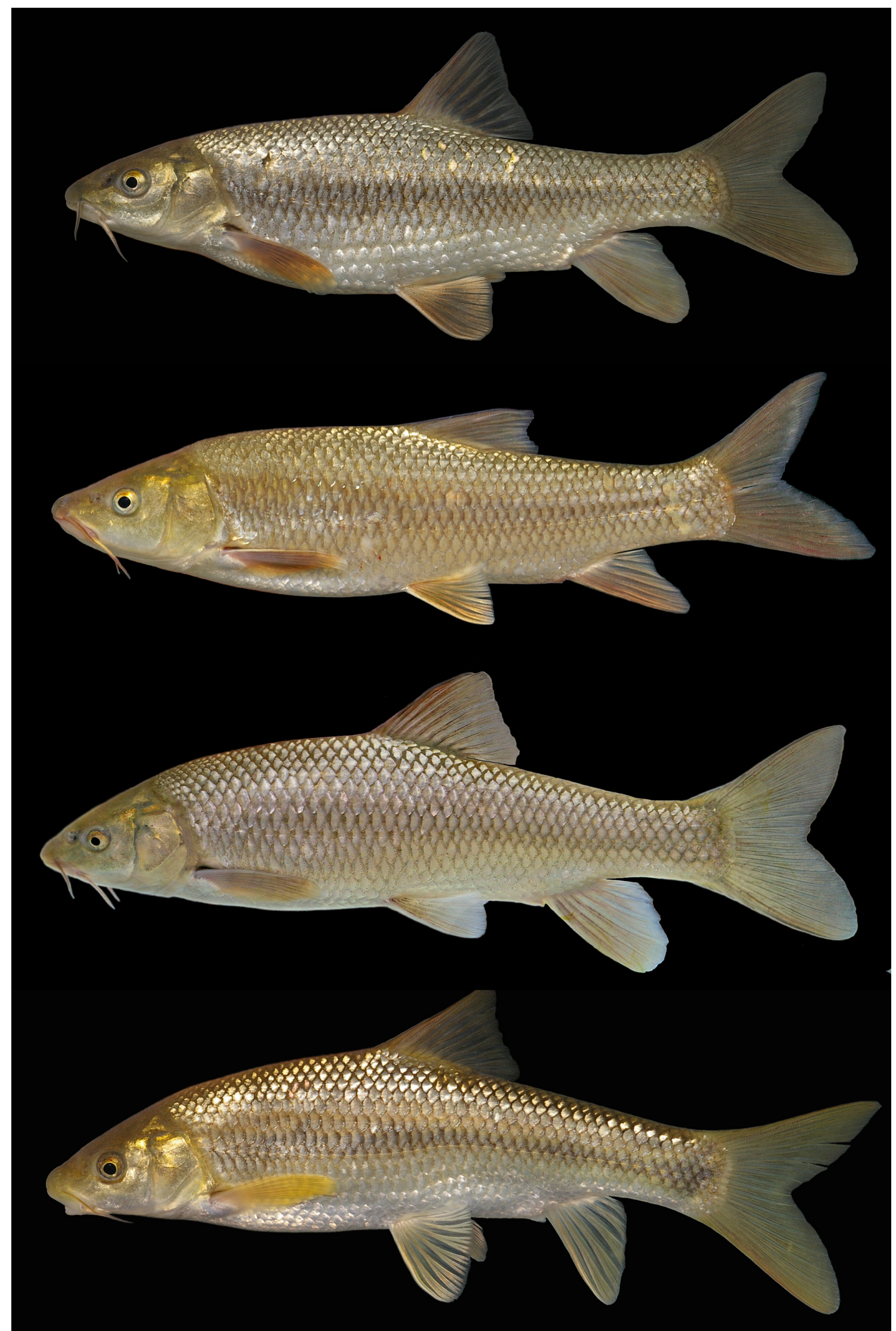

FIGURE 10. Luciobarbus species from the African Mediterranean basin. From the top. Luciobarbus leptopogon, FSJF 3284, $120 \mathrm{~mm}$ SL; Algeria: stream Meliji at Hammam Melouane; Luciobarbus rifensis, FSJF 3335, 220 mm SL; Morokko: Oued Laou near Chefchaouene; Luciobarbus setivimensis, FSJF 3292, $200 \mathrm{~mm}$ SL; Algeria: Oued Remila at inflow into Oued Soummam; Luciobarbus yahyaouii, FSJF 3313, 160 mm SL; Morocco: Oued Za near Guefaït. 


\section{Material used for molecular analyses}

Luciobarbus biscarensis. F01, F05, F06, Algeria: Biskra prov.: Loutaya River at Manbae, $35.094477^{\circ} \mathrm{N}$ $5.586152^{\circ} \mathrm{E}$ (38) (GenBank accession number: cyt b: KY828012, KY828013, KY828014; D-loop: KY828070, KY828071, KY828072 ).-E158, E159, E160, Gh222, Algeria: Biskra prov.: Oued el Abiod above damlake at Oued Lahbal, $34.867736^{\circ} \mathrm{N} 5.926079^{\circ} \mathrm{E}$ (41) (GenBank accession number: cyt b: KY828009, KY828010, KY828011, KY828015; D-loop: KY828067, KY828068, KY828069, KY828073).-S161, S163, S164, Algeria: $\mathrm{M}^{\circ}$ sila prov.: Ksob River, $35.840216^{\circ} \mathrm{N} 4.572089^{\circ} \mathrm{E}$ (37) (GenBank accession number: cyt b: KY828019, KY828020, KY828021; D-loop: KY828064, KY8280645, KY828066).-K33, K35, K55, Algeria: Khenchela prov.: El-Arab River at Babar, 35.166192 ${ }^{\circ} \mathrm{N} 7.020921^{\circ} \mathrm{E}$ (42) (GenBank accession number: cyt b: KY828016, KY828017, KY828018; D-loop: KY828061, KY828062, KY828063).

Luciobarbus callensis. T31, T32, Algeria: El-Taref prov.: Oued Bou-Namoussa in Seybouse drainage, $36.621504^{\circ} \mathrm{N} 8.057990^{\circ} \mathrm{E}(8)$ (GenBank accession number: cyt b: KY828028, KY828029; D-loop: KY828074, KY828075).-D139, D142, D147, D151, D153, D155, Algeria: Guelma prov.: Oued Bouhamdane at Hammam Debagh drainage, $36.468478^{\circ} \mathrm{N} 7.229560^{\circ} \mathrm{E}$ (9) (GenBank accession number: cyt b: KY828022, KY828023, KY828024, KY828025, KY828026, KY828027; D-loop: KY828076, KY828077, KY828078, KY828079, KY828080, KY828081).

Luciobarbus leptopogon. L93, L96, L99, L100, L102, L104, L105, Algeria: Blida prov.: Oued Hammam Melouane, $36.4829^{\circ} \mathrm{N}, 3.0414^{\circ} \mathrm{E}(16)$ (GenBank accession number: KY828003

KY828004, KY828005, KY828006, KY828007, KY828008; D-loop: KY828055, KY828056, KY828057, KY828058, KY828059, KY828060).

Luciobarbus setivimensis. Z07, Z14, Z30, Algeria: Bordj-Bou-Arreridj prov.: Ain Zada Dam at Ain Taghrout, $36.151209^{\circ} \mathrm{N} 5.159443^{\circ} \mathrm{E}(10)$ (GenBank accession number: cyt b: KY828052, KY828053, KY828054; D-loop: KY828104, KY828105, KY828106).

Barbus barbus. B01, B02, Belgium: Moha prov.: Mehaigne River, Meuse Basin, $50.5451^{\circ} \mathrm{N} 5.1164^{\circ}$ E.River drainage.

\section{Materials examined but not preserved.}

Luciobarbus biscarensis: 24, 242-308 mm SL; Algeria: Khenchela prov.: Oued el Arab at Babar, $35.166192^{\circ} \mathrm{N}$ $7.020921^{\circ} \mathrm{E}(42)$.

Luciobarbus callensis: 2, 313-334 mm SL; Algeria: El-Taref prov.: Oued Bou-Namoussa in Seybouse drainage, $36.621504^{\circ} \mathrm{N} 8.057990^{\circ} \mathrm{E}(8) .-19,205-292 \mathrm{~mm}$ SL; Algeria: Guelma prov.: Oued Bouhamdane at Hammam Debagh drainage, $36.468478^{\circ} \mathrm{N} 7.229560^{\circ} \mathrm{E}(9)$.

Luciobarbus leptopogon: 21, 82-175 mm SL; Algeria: Blida prov.: Oued Hammam Melouane, $36.4829^{\circ} \mathrm{N}$, $3.0414^{\circ} \mathrm{E}(16)$.

Luciobarbus setivimensis: 10, 187-363 mm SL; Algeria: Bordj-Bou-Arreridj prov.: Ain Zada Dam at Ain Taghrout, $36.151209^{\circ} \mathrm{N} 5.159443^{\circ} \mathrm{E}(10)$.

\section{Acknowledgements}

We thank all of those who contributed to this research: Nacer Tarai (Biskra University, Algeria), Mokhtar Kadjam (Director of Ouizert Dam, Mascara, Algeria), Abdelkader El-Najar, Fatah Boujamaa and Mourad Boujamaa (Algeria), Kai Borkenhagen (Büsum). We are also grateful for the assistance provided by Güse Serkan and Sebastian Hüllen (ZFMK). Emmanuel Vreven, Miguel Parrent, Jonathan Brecko and Aurore Mathys (RMCA) are thanked for their time and the pictures. We also thank Didier Van den Spiegel and Rudy Jocqué (RMCA) for their pertinent comments. Lastly, we thank Victoria Grace (www.english-publications.com) for editing the manuscript. This study was supported by the FREDIE project, supported by the Leibniz Association Joint Initiative for Research and Innovation (SAW). It is publication number BRC 390 of the Biodiversity Research Center, Université Catholique de Louvain, Belgium. 


\section{Literature cited}

Astrin, J.J., Stüben, P.E., Misof, B., Wägele, J.W., Gimnich, F., Raupach, M.J. \& Ahrens, D. (2012) Exploring diversity in cryptorhynchine weevils (Coleoptera) using distance-, character- and tree-based species delineation. Molecular Phylogenetics and Evolution, 63, 1-14. https://doi.org/10.1016/j.ympev.2011.11.018

Bazinet, A.L., Zwikhl, D.J. \& Cummings, M.P. (2014) Agateway for phylogenetic analysis powered by grid computing featuring GARLI 2.0. Systematic Biology, 63, 812-818. https://doi.org/10.1093/sysbio/syu031

Brahimi, A., Tarai, N., Benhassane, A., Henrard, A. \& Libois, R. (2016) Genetic and morphological consequences of Quaternary glaciations. A relic barbel lineage (Luciobarbus pallaryi, Cyprinidae) of the Guir Basin (Algeria). Comptes Rendus Biologie, 339, 83-98.

https://doi.org/10.1016/j.crvi.2015.12.003

Casal-Lopez, M., Perea, S., Yahyaoui, A. \& Doadrio, I. (2015) Taxonomic review of the genus Luciobarbus Heckel; 1843 (Actinopterygii, Cyprinidae) from northwestern Morocco with the description of three new species. Graellsia, 71, 1-24

Doadrio, I., Casal-López, L. Perea, S. \& Yahyaoui, A. (2016b) Taxonomy of rheophilic Luciobarbus Heckel, 1842 (Actinopterygii, Cyprinidae) from Morocco with the description of two new species. Graellsia, 72, 1-17. https://doi.org/10.3989/graellsia.2015.v71.135

Doadrio, I., Casal-López, M. \& Perea, S. (2016a) Taxonomic remarks on Barbus moulouyensis pellegrin, 1924 (Actinopterygii, Cyprinidae) with the description of a new species of Luciobarbus Heckel, 1843 from Morocco. Graellsia, 72, 1-24. https://doi.org/10.3989/graellsia.2016.v72.174

Felsenstein, J. (1981) Evolutionary tree from DNA sequences, a maximum likelihood approach, Journal of Molecular Evolution, 17, 368-376. https://doi.org/10.1007/BF01734359

Geiger, M.F., Herder, F., Monaghan, M.T., Almada, V., Barbieri, R., Bariche, M., Berrebi, P., Bohlen, J., Casal-Lopez, M., Delmastro, G.B. Denys, G.P., Dettai, A., Doadrio, I., Kalogianni, E., Kärst, H., Kottelat, M., Kovačić, M., Laporte, M., Lorenzoni, M., Marčić, Z., Özuluğ, M., Perdices, A., Perea, S., Persat, H., Porcelotti, S., Puzzi, C., Robalo, J., Šanda, R., Schneider, M., Šlechtová, V., Stoumboudi, M., Walter, S., Freyhof, J. (2014) Spatial heterogeneity in the Mediterranean Biodiversity Hotspot affects barcoding accuracy of its freshwater fishes. Molecular Ecology Resources, 14, 1210-1221. https://doi.org/10.1111/1755-0998.12257

Gouy, M., Guindon, S. \& Gascuel, O. (2010) SeaView Version 4: A Multiplatform Graphical User Interface for Sequence Alignment and Phylogenetic Tree Building. Molecular Biolology and Evolution, 27, 221-224. https://doi.org/10.1093/molbev/msp259

Hasegawa, M., Kishino, H. \& Yano, T. (1985) Dating of the human-ape split by a molecular clock by michondrial DNA. Journal of Molecular Evolution, 22, 160-174. https://doi.org/10.1007/BF02101694

Iguchi, K., Tanimura, Y. \& Nishida, M. (1997) Sequence divergence in the mtDNA control region of amphidromous and landlocked forms of ayu. Fish Sciences, 63, 901-905.

Katoh, K. \& Standley, D.M. (2013) MAFFT Multiple sequence alignment Software Version 7. Improvements in performance and usability. Molecular Biology and Evolution, 30, 772-780. https://doi.org/10.1093/molbev/mst010

Kimura, M. (1980) Estimation of evolutionary distances between homologous nucleotide sequences. Proceedings of the National Academy of Sciences USA, 78, 454-458 https://doi.org/10.1073/pnas.78.1.454

Lanave, C., Preparata, G., Saccone, C. \& Serio, G. (1984) A new method for calculating evolutionary substitution rates, Journal of Molecular Evolution, 20, 86-93. https://doi.org/10.1007/BF02101990

Lanfear, R., Frandsen, P.B., Wright, A.M., Senfeld, T. \& Calcott, B. (2017) PartitionFinder 2: new methods for selecting partitioned models of evolution for molecular and morphological phylogenetic analyses. Molecular Biolology and Evolution, 34, 772-773. https://doi.org/10.1093/molbev/msw260

Machordom, A. \& Doadrio, I. (2001) Evidence of a cenozoic Betic-Kabilian connection based on freshwater fish phylogeography (Luciobarbus, Cyprinidae). Molecular Phylogenetics and Evolution, 18, 252-263. https://doi.org/10.1006/mpev.2000.0876

Myers, N., Mittermeier, R., Mittermeier, C., da Fonseca, G. \& Kent, J. (2000) Biodiversity hotspots for conservation priorities. Nature, 403, 853-858. https://doi.org/10.1038/35002501

Nishida, M., Ohkawa, T. \& Iwata, H. (1998) Methods of analysis of genetic population structure with mitochondrial DNA markers. Fish Genetics and Breeding Science, 26, 81-100.

Palumbi, S.R. (1996) Nucleic acids II: The polymerase chain reaction. In: Hillis, D.M., Moritz, C. \& Mable, B.K. (Eds.), Molecular Systematic. $2^{\text {nd }}$ Edition. Sinauer, Sunderland, MA, pp. 5-247. 
Pellegrin, J. (1920) Poissons du Maroc recueillis par M. C. Alluaud. Bulletin du Museum dºHistoire Naturelle, Paris, 26, 612613. https://doi.org/10.5962/bhl.part.1209

Pellegrin, J. (1939) Les barbeaux de $1^{\circ}$ Afrique du Nord française: description d'une espèce nouvelle. Bulletin de la Société, des Sciences Naturelles du Maroc, 19, 1-4.

Perdices, A. \& Doadrio, I. (2001) The molecular systematics and biogeography of the European cobitids based on mitochondrial DNA sequences. Molecular Phylogenetics and Evolution, 19, 468-478. https://doi.org/10.1006/mpev.2000.0900

Rambaut, A. (2009) FigTree v1.4.2. Available from: http://tree.bio.ed.ac.uk/software/figtree/ (accesed 2 May 2017)

Rodríguez, F., Oliver, J.L., Marín, A. \& Medina, J.R. (1990) The general stochastic model of nucleotide substitution. Journal of Theoretical Biology, 142 (4), 485-501. https://doi.org/10.1016/S0022-5193(05)80104-3

Ronquist. F., Teslenko, M., Mark, P., Ayres, D.L., Darling, A., Höhna, S., Larget, B., Liu, L., Suchard, M.A. \& Huelsenbeck, J.P. (2012) MrBayes 3.2. Efficient Bayesian phylogenetic inference and model choice across a large, model space. Systematic Biology, 61, 539-542. https://doi.org/10.1093/sysbio/sys029

Sukumaran, J. \& Holder, M.T. (2010) DendroPy, a Python library for phylogenetic computing. Bioinformatics, 26, $1569-1571$. https://doi.org/10.1093/bioinformatics/btq228

Sukumaran, J. \& Holder, M.T. (2015) SumTrees. Phylogenetic tree Summarization, 4.0.0 Available from: https://github.com/ jeetsukumaran/Dendrophy (accessed 2 May 2017)

Talavera, G. \& Castresana, J. (2007) Improvement of phylogenies after removing divergent and ambiguously aligned blocks from protein sequence alignments. Systematic Biology, 56, 564-577. https://doi.org/10.1080/10635150701472164

Tavaré, S. (1986) Some probabilistic and statistical problems in the analysis of DNA sequences. Lectures on Mathematics in the Life Sciences (American Mathematical Society), 17, 57-86.

Tsigenopoulos, C.S., Durand, J.D., Ünlü, E. \& Berrebi, P. (2003) Rapid radiation of the Mediterranean Luciobarbus species (Cyprinidae) after the Messinian salinity crisis of the Mediterranean Sea, inferred from mitochondrial phylogenetic analysis. Biological Journal of the Linnean Society, 80, 207-222.

https://doi.org/10.1046/j.1095-8312.2003.00237.x 